\title{
Influence of surface texture and microhabitat heterogeneity in structuring nodule faunal communities
}

\author{
Julie Veillette ${ }^{1, *}$, S. Kim Juniper ${ }^{1,4}$, Andrew J.Gooday $^{2}$, Jozée Sarrazin ${ }^{3}$ \\ ${ }^{1}$ Centre GÉOTOP, Université du Québec à Montréal, C.P. 8888, Succursale Centre-Ville, Montréal, Québec H3C \\ 3P8, Canada \\ ${ }^{2}$ National Oceanography Centre, Southampton, University of Southampton Waterfront Campus, European Way, \\ Southampton, SO14 3ZH, UK \\ ${ }^{3}$ Institut Français de Recherche pour l'Exploitation de la MER/ Département Étude des Écosystèmes Profonds, \\ Centre de Brest BP 70, 29280 PLOUZANE, France \\ ${ }^{4}$ Present address: School of Earth and Ocean Sciences, University of Victoria, P.O. Box 3020, Victoria, British \\ Columbia V8W 3N5, Canada
}

*: Corresponding author : Julie Veillette, email address : julie.veillette.2@ulaval.ca

\begin{abstract}
:
Manganese nodules provide an important habitat for sessile benthic organisms, many of them novel foraminifera, in the abyssal Pacific. The surface texture and microhabitat heterogeneity of nodules may play a significant role in structuring these communities. We analyzed the distribution of foraminiferal species on 20 nodules collected using either a USNEL box corer or the Nautile submersible sampling tool at a 5000-m-deep site in the Tropical North Pacific. The nodules had an upper region characterized by two microhabitats, namely raised surfaces and intervening depressed surfaces. The more or less vertical sides of the nodules were regarded as a third microhabitat. The upper region had a predominantly smooth texture while the sides had a rough texture. We tested whether the percent cover of each of the 34 species examined was distributed evenly over the three microhabitats and the two surface textures (smooth vs rough). More than half (20 out of 34 ) of species covered a greater area on smooth surfaces than on rough surfaces, while one-third of the species (12 out of 34) occurred more on raised microhabitats than on depressed surfaces and nodule sides. These two results are closely interrelated, since $78 \%$ of the raised surfaces were characterized by a smooth texture. The nodule-encrusting species were feeding either on suspended particles or on particles deposited on the nodule surfaces. Because most species had a mat-like or domed morphology, we suspect that nodule surface feeding was more prevalent. Current flow, which transports propagules and particulate food, may be the main environmental factor explaining the observed faunal distributions, as it is in the case of other hard-substrate assemblages.
\end{abstract}

Keywords: Ferromanganese nodules; Epifauna; Agglutinated foraminifera; Surface texture; Microhabitats; Current flow

Pacific Ocean; Equatorial North Pacific Ocean; Clarion-Clipperton Fracture Zone $\left(14^{\circ} \mathrm{N} ; 130^{\circ} \mathrm{W}\right)$ 


\section{Introduction}

Benthic foraminifera are often a dominant component of deep-sea, soft-bottom communities, particularly at abyssal depths (Snider et al., 1984; Gooday, 2003). These testate protists are also abundant on hard structures in the deep ocean, mainly manganese nodules, glacial drop stones and biogenic structures including the tests of other, larger foraminifera, as well as experimental settlement plates (Lipps, 1983; Gooday 1990; Bertram and Cowen, 1999; Hughes and Gooday, 2004). In tropical latitudes, the most prevalent hard substratum in the deep ocean is provided by extensive tracts of manganese nodules, which are densely encrusted with organisms, most of them foraminifera (Dugolinsky et al., 1977; Mullineaux, 1987). As in the case of sediment-dwelling communities, these sessile foraminifera are undoubtedly important in terms of their contribution to benthic biomass and diversity and, their ecological role, although both these aspects of their biology remain poorly understood.

In a companion paper to the present study, Veillette et al. (in press) described faunal assemblages from manganese nodules at two sites (east and west zones) in the Clarion-Clipperton Fracture Zone, eastern Equatorial Pacific. They recognized four facies defined by nodule characteristics: three (facies A, B and C) were found in the east zone and a single facies was identified in the west zone. They described the foraminiferan and metazoan assemblages associated with the nodules and related 
faunal coverage, species richness and species density to nodule characteristics at the facies and regional (east vs west zones) scale. Veillette et al. (in press) suggested that microhabitat heterogeneity created by complex, knobby nodule micro-relief and the remnants of biogenic structures might enhance the species richness of sessile organisms and increase faunal cover. However, they did not investigate the spatial relationship between species and small-scale surface features (microhabitats) of the nodules.

Because of the dependence of sessile, hard-substrate organisms on currents, flow velocity is often considered to be the most important environmental parameter structuring sessile hard-substrate communities (Jumars and Nowell, 1984; Mullineaux, 1988; Lutze and Thiel, 1989; Flach et al., 1998; Pernet et al., 2003; Thistle, 2003). Currents can affect the way in which organisms colonize hard substrata. For example, interactions between boundary-layer flow and surface characteristics, including composition and microtopography, may influence where larvae and other propagules settle and hence the ways in which organisms colonize hard substrata (Mullineaux, 1989; Mullineaux and Butman, 1990). Similarly, small substratum irregularities may affect the current velocities experienced by sessile benthic organisms (Mullineaux 1989), many of which depend on the water flow for their food. Substratum characteristics, such as surface texture, can influence the distribution of foraminifera (Mullineaux, 1988; Gooday, 1990; Bertram and Cowen, 
1994, 1999) and were also observed to vary between different areas of the surfaces of nodules analyzed by Veillette et al. (in press).

In this paper, we explore the relation between different regions ('microhabitats') and surface textures (rough vs smooth) of individual nodules from our equatorial Pacific study area and the distribution of 34 species of encrusting foraminifera. Specifically, we ask: 1) Is there an association between particular species and specific microhabitats on the nodule surface? and 2) Are different species associated with areas of rough and smooth surface texture?

\section{Materials and methods}

\subsection{Sampling sites and methods}

Samples were collected during the NODINAUT cruise (RV l'Atalante; May $18^{\text {th }}-$ June $\left.27^{\text {th }} 2004\right)$ in two areas, the east zone $\left(14^{\circ} \mathrm{N}, 130^{\circ} \mathrm{W}\right)$ and the west zone $\left(9^{\circ} \mathrm{N}\right.$, $150^{\circ} \mathrm{W}$ ), of the French mining claim in the equatorial Pacific. Both are located in the Clarion-Clipperton Fracture Zone between 4950 and 5050 m water depth, below the carbonate compensation depth, where sediments are fine-grained clays (Skornyakova and Murdmaa, 1992). Primary productivity in this region is estimated to be moderate compared to the high equatorial productivity (Du Castel, 1985; Skornyakova and Murdmaa, 1992). Bottom-water temperature was $\sim 1^{\circ} \mathrm{C}$ and near-bottom currents 
observed during the NODINAUT cruise (short term ADCP-WH300 measurements at ten meters above the bottom, Vangriesheim, unpublished data) were very weak (3.5 $\left.4 \mathrm{~cm} \mathrm{~s}^{-1}\right)$.

The four nodule facies recognized by Veillette et al. (in press) differed in nodule shape, size, surface morphology and the degree to which nodules were exposed above the sediment-water interface. Twenty nodules from facies $\mathrm{C}$ in the east zone were chosen for this study, because they exhibited greater microhabitat heterogeneity and surface texture variations than other nodules. Facies $C$ nodules formed spheres that were half buried in the sediment and covered an estimated $40 \%$ of the seafloor. They were generally larger (average diameter $11 \mathrm{~cm}$ ) than nodules from other facies, but their sizes varied considerably, ranging from 2 to $15 \mathrm{~cm}$ diameter. The upper, summit region of the nodules was characterized by knobs and protrusions but otherwise had a generally smooth texture, whereas the sides were rough. Only nodules whose vertical or near-vertical sides extended more than $30 \mathrm{~mm}$ above the sediment were included in the present study.

Nodules were sampled using either a USNEL box corer or the manipulator of the Nautile submersible (Veillette et al., in press). The sampled nodules were preserved in $4 \%$ formaldehyde and transferred to $70 \%$ alcohol after several days. They were all carefully packed for transportation in jars of different sizes. Plastic packing was placed in the jars to immobilize the nodules. During all manipulations, nodules were 
never allowed to dry and were handled with the greatest care possible because of their high friability.

\subsection{Nodule surface area determination}

Nodule surface area above the sediment-water interface was estimated in order to calculate percent cover on the different textures and microhabitats. Since nodule surfaces below the sediment line were rarely colonized, they were not examined further. The 20 nodules analyzed in this study had vertical or near-vertical sides that extended for more than $30 \mathrm{~mm}$ above the sediment surface before flattening to form the upper region. We therefore differentiated between the upper and side regions of each nodule. Upper surface area was determined using IP Lab Spectrum $\subset$ image analysis software, assuming that top-view photographs provided a good representation of the upper surface. Side surface area was calculated using the surface formula for an open cylinder (height x circumference). Because most nodules were irregular in shape, the height of the sides was measured at every $45^{\circ}$ point around the nodule circumference. All measurements and surface area determinations with IP Lab Spectrum $($ were made in triplicate.

\subsection{Faunal identification and quantification}


Living organisms on nodule surfaces were identified using a binocular dissecting microscope. High power light microscopy and scanning electron microscopy were also used to examine smaller forms or to decide if particular forms were protozoans, metazoans or non-biogenic structures. The tests of most foraminifera (protozoa) were partially broken in order to determine if protoplasm was present and therefore whether the organism was alive or dead. However, some foraminifera, for example, komokiacean-like forms in which the test interior is dominated by stercomata, rarely contained visible protoplasm. In these cases, unbroken tests were regarded as being live when collected. Despite all precautions taken during handling of the nodules, some very fragile structures may have been destroyed or lost prior to identification. Thus, the recognition of species may have been biased towards more robust forms firmly attached to nodule surfaces. Two foraminiferal feeding types were distinguished based on test contents: species containing cytoplasm without obvious accumulations of stercomata and species that accumulate stercomata and have sparse cytoplasm (Gooday et al., 1997, in press). We refer to these as 'feeding type I' and 'feeding type II', respectively.

The vast majority of the living organisms on the nodules were mat-like or domeshaped foraminifera. Only these encrusting species were included in this study. Following Mullineaux (1987), they were quantified in terms of percent cover. For many species, the numbers of specimens, and hence faunal densities, could not be calculated easily because it was difficult to define the limits of an individual. Upright 
structures were excluded, since the surface area that they covered was negligible. In order to simplify the estimation of surface area covered, each specimen was approximated to a circle or a rectangle. The dimensions of the test were then measured under a binocular microscope equipped with an eyepiece scale. For species forming anastomosing networks, the percentage of nodule surface covered within the boundaries of the test was estimated by eye. The species included in this study were those found on at least two nodules.

\subsection{Microhabitats and definition of surface textures}

Data from twenty nodules were pooled to investigate the influence of microhabitats and surface texture on the distribution of nodule fauna. Three different microhabitats were recognized on all nodules. Raised surfaces and depressed surfaces on the upper region constituted two distinct microhabitats, the depressions being the spaces between two or more raised areas of the nodule surface (Fig. 1). The sides of the nodule formed the third microhabitat.

We defined surface texture as either smooth or rough, although it was sometimes difficult to classify areas of moderate roughness. Smooth surfaces lacked protrusions visible to the naked eye, whereas rough surfaces had a gritty appearance similar to that of sandpaper. The surface area characterised by each texture was estimated for the upper region of each of the 20 nodules analyzed by recording the texture under 20 
random points of a grid placed over the nodule summit. Sides were dominated by rough surfaces.

\subsection{Statistical analyses}

A Kruskal-Wallis test was performed for the 34 live species included in this study in order to test for significant differences in cover between (1) microhabitats and (2) surface textures. The area covered by each species on each microhabitat was divided by the fraction of the nodule represented by that microhabitat in order to calculate percent cover per microhabitat. The same was done for the comparisons between the two surface textures.

\section{Results}

When the 20 nodules were pooled, 86\% of the combined upper area was occupied by raised microhabitats, the remaining areas being depressions (Fig. 1). Seventy-two percent of the combined upper area had a smooth surface texture. When only the raised microhabitat was considered, $78 \%$ of the surface texture was smooth, whereas only $30 \%$ of the depressed microhabitat had a smooth surface texture. When the areas occupied by the three microhabitats from the 20 nodules were combined, smooth and rough surfaces were almost equally represented (48\% versus 52\%, respectively). 
Raised microhabitats represented 57\%, sides 33\% and depressed microhabitats 10\% of the total exposed area of the nodule surface.

Twelve of the 34 species examined occurred more on raised surfaces than on depressed surfaces and nodule sides. The percent cover of 20 species (out of 34) was significantly different between the two surface textures (Table 1). In all cases, the percent cover was greater on smooth surfaces. Of these 20 species, 13 contain protoplasm (feeding type I), six accumulated stercomata (feeding type II) and one could not be assigned to either category. Fourteen species occurred more on smooth and raised surfaces than on depressed surfaces and nodule sides; 8 of them belonged to feeding type I and 5 to feeding type II. Overall, 12 species had no significant relationships with either microhabitat types or surface texture.

\section{Discussion}

\subsection{Feeding types}

Foraminifera that contain cytoplasm but are devoid of obvious stercomata and those that have sparse cytoplasm and large accumulations of stercomata (our feeding types I and II respectively) appear to represent different trophic strategies (Gooday et al., 1997; in press). Type II species, which include the komokiaceans, are particularly abundant in abyssal, oligotrophic settings (Nozawa et al., 2006) and it is not 
surprising to find that they are common on nodule surfaces. Stercomata are waste pellets that consist largely of tiny, flake-like mineral grains (Riemann, 1983). Sediment-dwelling species that accumulate stercomata probably obtain grains from the surrounding sediment and therefore can be considered deposit feeders. However, foraminifera living on nodules, particularly those found on the upper region, do not have direct access to the sediment. Instead, the tiny clay-sized grains that form the stercomata of type II species must be taken directly either from the water column or from material deposited on the nodule surface (Burnett and Nealson, 1983). Type I species presumably feed on bacteria and other small particles and expel any sediment grains that they ingest. Food particles could be obtained either from suspension or from organic films and associated microorganisms present on the nodule surface (Burnett and Nelson, 1981; Bernhard and Bowser, 1992). Thus, foraminifera of both types may be feeding on material in suspension or material present on the nodule surface, or they may combine suspension and surface feeding. Xenophyophores, giant protozoans that accumulate large quantities of stercomata, seem to be capable of both suspension (Levin and Thomas, 1988) and deposit feeding (Gooday et al., 1993). Since all the species we analysed were encrusting forms with more or less flat, matlike or domed morphologies, we speculate that nodule surface feeding was more prevalent. Occasional foraminifera with erect morphologies typical of suspension feeders (Lipps, 1983) were present on the nodule surfaces (see supplementary material of Veillette et al., in press) but were not included in our analyses and represented a minor component of the assemblage. 


\subsection{Controls on distributions}

Some authors have found that foraminifera usually colonize nodule surfaces at, or just above, the sediment-water interface (Greenslate, 1974; Dugolinsky, 1976;

Dugolinsky et al., 1977; von Stackelberg, 1984). Mullineaux (1988), however, reported that $65 \%$ of the sessile organisms living on nodules belonged to species whose abundance was related to vertical position on the nodule. This agrees with our observation that almost half of the species we analyzed covered more substratum area near the summit than on the sides of the nodules. In addition to nodule surface microhabitats, foraminifera can live in crevices and cavernous spaces within nodules, where they presumably gain shelter from predators and possibly access to bacterial food (von Stackelberg, 1984; Maybury, 1996). However, neither the crevice microhabitat nor the predominantly spherical foraminiferal morphotypes that inhabit it were represented in our material.

Surface texture perception by organisms depends partly on their size. An organism similar in size to the protrusions creating the surface roughness will probably be influenced differently compared to a larger organism. Nevertheless, differences between smooth and rough nodule surfaces may be large enough to be detected by invertebrate larvae (Mullineaux, 1989) and possibly also by foraminiferal propagules. The nodules that we examined had a predominantly smooth upper region and rough 
sides, as also observed by Dugolinsky $(1976)$ and Mullineaux $(1988,1989)$ in other parts of the Pacific Ocean. As in our study, Mullineaux (1989) found that more species (16) were concentrated on smooth surfaces than on rough surfaces (9 species). She concluded that these faunal distributions probably resulted from interactions between texture, flow, and particulate food availability, rather than on texture alone (Mullineaux, 1989).

Flow is a crucial parameter for sessile organisms living on hard substrata since it transports larvae and other propagules, influences their settlement, and delivers food to suspension feeders (Mullineaux, 1988; Mullineaux and Butman, 1990; Pernet et al., 2003; Thistle, 2003). In areas characterized by strong currents, foraminifera often colonize stones and elevated biogenic structures (Schönfeld 1997, 2002; Lutze and Altenbach, 1988; Lutze and Thiel, 1989; Linke and Lutze, 1993). From these vantage points, they are able to extend their pseudopodial network into the velocity profile of the near-bottom shear flow and take advantage of the enhanced food supply (Lipps, 1983). Large, suspension-feeding animals colonizing other marine hard substrata also often occupy positions that allow them to take advantage of enhanced particle fluxes (Mullineaux, 1988; Etter and Mullineaux, 2001). For instance, suspension-feeding corals on seamounts appear to benefit from flow acceleration, and current conditions influence their distribution patterns (Genin et al., 1986). According to Beaulieu (2001), suspension-feeding organisms, including a zoanthid, a tunicate, ophiuroids and anemones, preferentially colonized the tops of sponge stalks. 
In our study, 12 out of 34 foraminiferal species, representing both feeding types, occurred mostly on raised nodule surfaces, i.e. elevated microhabitats (Table 1). The predominantly smooth upper surfaces of the nodules probably experience a higher flow velocity, because they project further into the benthic boundary layer (Thistle, 2003). As a result, and irrespective of whether the foraminifera were consuming suspended particles or organic material deposited on the nodule surface, the food supply is likely to have been enhanced in the summit region of the nodule. Thus location on the nodule, rather than texture, probably explains why many species were more abundant on smooth surfaces. A rough surface texture could also enhance the accumulation of fine particles and hence food availability for nodule surface feeders (Burnett and Nealson, 1983), although none of the species that we recognised exhibited a significant relationship with rough surfaces.

\subsection{Other possible factors}

Foraminifera may also mainly colonize raised nodule surfaces because these areas may favour propagule deposition. These may be areas where foraminiferal propagules are preferentially deposited from the water column. Biotic factors can structure attached faunal communities. For example, Beaulieu (2001) suggested that vertical zonation on sponge stalks was determined mostly by interactions among species. In the present case, however, such interactions seem to have little influence on nodule 
fauna (Veillette et al., in press). Biotic disturbance, including physical disruption and mortality due to predation, may also decrease larval settlement (Osman and Whitlatch, 1995). In hypoxic and sulphidic environments, foraminifera often climb up raised microhabitats in order to avoid oxygen depletion and hydrogen sulfide toxicity at the sediment-water interface (Linke and Lutze, 1993; Alve and Bernhard, 1996; Sen Gupta et al., 2007). However, this is unlikely to be a factor in the welloxygenated environment of the abyssal Pacific.

\section{Conclusion}

This study explored the influence of microhabitat heterogeneity and surface texture on the structure of foraminiferal assemblages attached to the surfaces of manganese nodules in the Clipperton-Clarion Fracture Zone. These assemblages may contribute substantially to overall levels of benthic diversity in this and other parts of the abyssal Pacific. Three microhabitats (raised surfaces, depressed surfaces, and nodule sides) and two surface textures (smooth and rough) were recognised. Most of the summit region of the nodules was occupied by raised microhabitats and had a smooth texture. These smooth, raised surfaces were the most colonized by many of the 34 species analysed. We suggest that current flow, which will be higher on raised surfaces, is the main environmental factor controlling the observed distribution pattern. Therefore, vertical distance from the sediment should be a good predictor of faunal cover on nodule surfaces. Given the possibility of future nodule mining, this type of 
information is essential in order to establish an ecological baseline for attached nodule faunas.

\section{Acknowledgements}

This research would not have been possible without the help of the NODINAUT scientific party. We extend great thanks to everyone in the Laboratoire Environnement Profond of Ifremer in Brest and to Ifremer for its financial support. We also thank the Atalante ship crew and Nautile pilots as well as Joëlle Galéron, chief scientist of the cruise. A.J. Gooday participated in this study as part of the project "Biodiversity, species ranges, and gene flow in the abyssal Pacific nodule province: Predicting and managing the impacts of deep seabed mining” supported by the Kaplan Foundation and International Seabed Authority. J. Veillette was also supported by an NSERC Canada Discovery grant to S.K. Juniper. This research partially fulfilled requirements for a Masters degree in Environmental Sciences by the senior author at Université du Québec à Montréal.

\section{References}

Alve, E. and Bernhard, J.M. 1995. Vertical migratory response of benthic foraminifera to controlled oxygen concentrations in an experimental mesocosm. Marine Ecology Progress Series 116, 137-151.

Beaulieu, S.E., 2001. Life on glass houses: sponge stalk communities in the deep sea. Marine Biology 138, 803-817. 
Bernhard, J.M. and Bowser, S.S., 1992. Bacterial biofilms as a trophic resource for certain benthic foraminifera. Marine Ecology Progress Series 83, 263-272.

Bertram, M.A. and Cowen, J.P., 1994. Testate rhizopod growth and mineral deposition on experimental substrates from Cross Seamount. Deep-Sea Research I 41, 575-601.

Bertram, M.A. and Cowen, J.P., 1999. Temporal variations in the deep-water colonization rates of small benthic foraminifera: the results of an experiment on Cross Seamount. Deep-Sea Research I 46, 1021-1049.

Burnett, B.R. and Nealson, K.H., 1981. Organic films and microorganisms associated with manganese nodules. Deep-Sea Research 28A (6), 637-645.

Burnett, B.R. and Nelson, K.H., 1983. Energy dispersive X-ray analysis of the surface of a deep-sea ferromanganese nodule. Marine Geology 53, 313-329.

Du Castel, V., 1985. Établissement d'une carte géologique au 1/20000 d'un domaine océanique profond dans une zone riche en nodules polymétalliques du Pacifique Nord (zone Clarion-Clipperton). Thèse de doctorat, Brest, unpublished.

Dugolinsky, B.K., 1976. Chemistry and morphology of deep-sea manganese nodules and the significance of associated encrusting protozoans on nodule growth. Ph.D. thesis, unpublished.

Dugolinsky, B.K., Margolis, S.V. and Dudley, W.C., 1977. Biogenic influence on growth of manganese nodules. Journal of Sedimentary Petrology 47, 428-445.

Etter, R.J. and Mullineaux, L.S., 2001. Deep-sea Communities. In: Bertness, M.D., Gaines, S.D. and Hay, M.E. (Eds.), Marine Community Ecology. Sinauer Associates, Inc., Sunderland, Massachusetts, pp. 367-393.

Flach, E., Lavaleye, M., deStigter, H. and Thomsen, L., 1998. Feeding types of the benthic community and particle transport across the slope of the N.W. European continental margin (Goban Spur). Progress in Oceanography 42, 209-231.

Genin, A., Dayton, P.K., Lonsdale, P.F. and Spiess, F.N., 1986. Corals on seamount peaks provide evidence of current acceleration over deep-sea topography. Nature 322, 59-61.

Gooday, A.J., 1990. Recent deep-sea agglutinated foraminifera: a brief review. In: Hemleben, C. et al. (Eds.), Paleoecology, Biostratigraphy, Paleoceanography and 
Taxonomy of Agglutinated Foraminifera. Kluwer Academic Publishers, Netherlands, pp. 271-304.

Gooday, A.J. 2003. Benthic foraminifera (Protista) as tools in deep-water palaeoceanography: a review of environmental influences on faunal characteristics. Advances in Marine Biology 46, 1-90.

Gooday, A. J., Bett, B. and Pratt, D.N., 1993. Direct observation of episodic growth in an abyssal xenophyophore (Protista). Deep-Sea Research I 40 (11/12), 2131-2143.

Gooday, A. J., Shires, R. and Jones, A. R., 1997. Large, deep-sea agglutinated foraminifera: two differing kinds of organization and their possible ecological significance. Journal of Foraminiferal Research 27 (4), 278-291.

Gooday, A.J., Nomaki, H. and Kitazato, H., in press. Modern deep-sea benthic foraminifera: a brief review of their biodiversity and trophic diversity. Geological Society of London Special Publication.

Greenslate, J., 1974. Microorganisms participate in the construction of manganese nodules. Nature 249, 181-183.

Hughes, J.A. and Gooday, A.J., 2004. Associations between living benthic foraminifera and dead tests of Syringammina fragilissima (Xenophyophorea) in the Darwin Mounds region (NE Atlantic). Deep-Sea Research I 51, 1741-1758.

Jumars, P.A. and Nowell, A.R.M., 1984. Fluid and sediment dynamic effects on marine benthic community structure. American Zoologist 24, 45-55.

Levin, L. A. and Thomas, C. L., 1988. The ecology of xenophyophores (Protista) on eastern Pacific seamounts. Deep-Sea Research 35 (12), 2003-2027.

Linke, P. and Lutze, G.F., 1993. Microhabitat preferences of benthic foraminifera - a static concept or a dynamic adaptation to optimize food acquisition? Marine Micropaleontology 20, 215-234.

Lipps, J.H., 1983. Biotic interactions in benthic foraminifera. In: Tevesz, M.J.S. and McCall, P.L.(Eds),. Biotic Interactions in Recent and Fossil Benthic Communities. Plenum Publishing Corporation, New York. pp. 331-376.

Lutze, G.F. and Altenbach, A.V. 1988. Rupertina stabilis (Wallich), a highly adapted, suspension feeding foraminifer. Meyniana 40, 55-69. 
Lutze, G.F. and Thiel, H., 1989. Epibenthic foraminifera from elevated microhabitats: Cibicidoides wuellerstrofi and Planulina ariminensis. Journal of Foraminiferal Research 19, 153-158.

Maybury, C., 1996. Crevice foraminifera from abyssal South East Pacific manganese nodules. In: Moguilevsky, A. and Whatley, R. (Eds.), Microfossils and Oceanic Environments. Aberystwyth-Press, University of Wales, pp. 281-295.

Morgan, C.L., Odunton, N.A. and Jones, A.T., 1999. Synthesis of environmental impacts of deep seabed mining. Marine Georesources and Geotechnology 17, 307356.

Mullineaux, L.S., 1987. Organisms living on manganese nodules and crusts: distribution and abundance at three North Pacific sites. Deep-Sea Research 34, 165184.

Mullineaux, L.S., 1988. The role of settlement in structuring a hard-substratum community in the deep sea. Journal of Experimental Marine Biology and Ecology $120,247-261$.

Mullineaux, L.S., 1989. Vertical distributions of the epifauna on manganese nodules: Implications for settlement and feeding. Limnology and Oceanography 34, 12471262.

Mullineaux, L.S. and Butman, C.A., 1990. Recruitment of encrusting benthic invertebrates in boundary-layer flows: A deep-water experiment on Cross Seamount. Limnology and Oceanography 35, 409-423.

Nozawa, F., Kitazato, H., Tsuchiya, M. and Gooday, A.J., 2006. 'Live’ benthic foraminifera at an abyssal site in the equatorial Pacific nodule province: Abundance, diversity and taxonomic composition. Deep-Sea Research I 53, 1406-1422.

Osman, R.W. and Whitlatch, R.B., 1995. The influence of resident adults on larval settlement: experiments with four species of ascidians. Journal of Experimental Marine Biology and Ecology 190, 199-220.

Pernet, F., Tremblay, R. and Bourget, E., 2003. Settlement success, spatial pattern and behavior of mussel larvae Mytilus spp. in experimental 'downwelling' systems of varying velocity and turbulence. Marine Ecology Progress Series 260, 125-140.

Riemann, F., 1983. Biological aspects of deep-sea manganese nodule formation. Oceanologica Acta 6 (3), 303-311. 
Saguez, G., 1985. Étude de la morphologie, de la structure interne et de la lithologie des nodules polymétalliques de la zone Clarion-Clipperton: relations avec l'environnement. Ph.D. Thesis, Brest, unpublished.

Schönfeld, J., 1997. The impact of the Mediterranean Outflow Water (MOW) on benthic foraminiferal assemblages and surface sediments at the southern Portuguese continental margin. Marine Micropaleontology 29, 211-236.

Schönfeld, J., 2002. Recent benthic foraminiferal assemblages in deep high-energy environments from the Gulf of Cadiz (Spain). Marine Micropaleontology 44, 141162.

Sen Gupta, B.K., Smith, L.E. and Lobegeier, M.K., 2007. Attachment of Foraminifera to vestimentiferan tubeworms at cold seeps: Refuge from seafloor hypoxia and sulfide toxicity. Marine Micropaleontology 62, 1-6.

Skornyakova, N.S. and Murdmaa, I.O., 1992. Local variations in distribution and composition of ferromanganese nodules in the Clarion-Clipperton Nodule Province. Marine Geology 103, 381-405.

Snider, L.J., Burnett, B.R. and Hessler, R.R., 1984. The composition and distribution of meiofauna and nanobiota in a central North Pacific deep-sea area. Deep-Sea Research 31, 1225-1249.

Thistle, D., 2003. The Deep-Sea Floor: an Overview. In: Tyler, P.A. (Ed.), Ecosystems of the Deep Oceans 28. Elsevier, Amsterdam, pp. 5-37.

Veillette, J., Sarrazin, J., Gooday, A. J., Galéron, J., Caprais, J.-C., Vangriesheim, A., Christian, J.R. et Juniper, S.K., 2007. Ferromanganese nodule fauna in the tropical North Pacific Ocean: species richness, faunal cover and spatial distribution. Deep-Sea Research I. In press.

von Stackelberg, U., 1984. Significance of benthic organisms for the growth and movement of manganese nodules, Equatorial North Pacific. Geo-Marine Letters 4, $37-42$. 
Table 1. Distribution of the 34 foraminiferal species (percent cover) according to microhabitat (raised surfaces (R), depressed surfaces (D) and sides (S)) and nodule surface texture (smooth and rough). ${ }^{*} \alpha=0.05, * * \alpha=0.01, * * * \alpha=0.001$. Feeding types I (containing cytoplasm) and II (accumulations of stercomata, sparse cytoplasm) are indicated after the name of the species. NS: non-significant. See supplementary material of Veillette et al. (in press) for photograph and description of every taxon.

\begin{tabular}{|c|c|c|c|}
\hline & Species & $\begin{array}{l}\text { Microhabitat } \\
\text { most covered }\end{array}$ & $\begin{array}{l}\text { Surface } \\
\text { texture most } \\
\text { covered }\end{array}$ \\
\hline 2 & Hemispherammina-like, pale regular dome (I) & $\mathrm{R}>\mathrm{D}$ and $\mathrm{S} * * *$ & Smooth *** \\
\hline 3 & Hemispherammina-like, pale granular dome (I) & NS & Smooth ** \\
\hline 4 & Hemisperammina-like, irregular shape (I) & NS & Smooth ** \\
\hline 5 & Tholosina sp. (I) & $\mathrm{R}>\mathrm{D}$ and $\mathrm{S} * * *$ & Smooth *** \\
\hline 6 & Tholosina-like (I) & NS & Smooth * \\
\hline 8 & Placopsilina-like (I) & NS & NS \\
\hline 9 & Komoki, mud-ball type (II) & NS & NS \\
\hline 13 & Ammocibicides-like (I) & $\mathrm{R}>\mathrm{D}$ and $\mathrm{S} * *$ & Smooth * \\
\hline 14 & Fine agglutinated particles beige soft dome (I) & NS & NS \\
\hline 15 & Brown granular shiny dome (II) & NS & NS \\
\hline 17 & Black soft dome (II) & $\mathrm{R}>\mathrm{D}$ and $\mathrm{S} * *$ & NS \\
\hline 18 & Orange dome (I) & NS & NS \\
\hline 19 & Chondrodapis hessleri (II) & $\mathrm{R}>\mathrm{D}$ and $\mathrm{S} *$ & Smooth ** \\
\hline 20 & Chondrodapis integra (II) & $\mathrm{R}>\mathrm{D}$ and $\mathrm{S} * * *$ & Smooth *** \\
\hline 21 & $\begin{array}{l}\text { Area covered with komokiacean-like chambers linked } \\
\text { with fine tubes (II) }\end{array}$ & NS & NS \\
\hline 22 & Grey granular mat (II) & $\mathrm{R}>\mathrm{D}$ and $\mathrm{S} * *$ & Smooth ** \\
\hline 23 & $\begin{array}{l}\text { Very thin muddy patches with komokiacean-like } \\
\text { chambers (II) }\end{array}$ & NS & Smooth *** \\
\hline 25 & Tumidotubus (I) & $\mathrm{R}$ and $\mathrm{S}>\mathrm{D} * *$ & NS \\
\hline 28 & "White crust" (I) & $\mathrm{R}>\mathrm{D}$ and $\mathrm{S} * * *$ & Smooth $* * *$ \\
\hline 29 & "Beige filamentous mat" & NS & NS \\
\hline 30 & "Dark chambered mat" (II) & NS & NS \\
\hline 31 & Thin grey mat (I) & $\begin{array}{l}\mathrm{R}>\mathrm{D} ; \mathrm{S}=\mathrm{R} \\
\mathrm{S}=\mathrm{D} \text { *** }\end{array}$ & Smooth ** \\
\hline 32 & Thin organic mat with dark grey stercomata (II) & $\mathrm{R}>\mathrm{D}$ and $\mathrm{S} * * *$ & Smooth *** \\
\hline 34 & Beige thick and smooth mat, interior brown (I) & $\begin{array}{l}\mathrm{R}>\mathrm{D} ; \mathrm{S}=\mathrm{R} ; \\
\mathrm{S}=\mathrm{D} *\end{array}$ & Smooth * \\
\hline 35 & Mat of blue flattened chambers & $\mathrm{R}>\mathrm{D}$ and $\mathrm{S} * * *$ & Smooth *** \\
\hline 36 & White mat with lumps (I) & NS & Smooth * \\
\hline 42 & Reticulated dark tunnels (I) & NS & Smooth * \\
\hline 43 & $\begin{array}{l}\text { Network of beige tunnels; horizontal tree with upright } \\
\text { branches (II) }\end{array}$ & NS & NS \\
\hline 44 & Crystal star and tunnels (I) & $\begin{array}{l}\mathrm{R}>\mathrm{S} ; \mathrm{D}=\mathrm{R} \\
\mathrm{D}=\mathrm{S} * *\end{array}$ & Smooth ** \\
\hline 45 & Spider network of grey tunnels (I) & $\mathrm{R}>\mathrm{D}$ and $\mathrm{S} * *$ & Smooth ** \\
\hline 46 & White soft tunnels (I) & NS & NS \\
\hline 49 & "Flattened chambers" (II) & $\mathrm{R}>\mathrm{D}$ and $\mathrm{S} * * *$ & Smooth *** \\
\hline
\end{tabular}


51 Hormosina sp. (I)

65 Anastomosing Rhizammina-like (II)

NS

NS

NS

NS 
Figure 1.

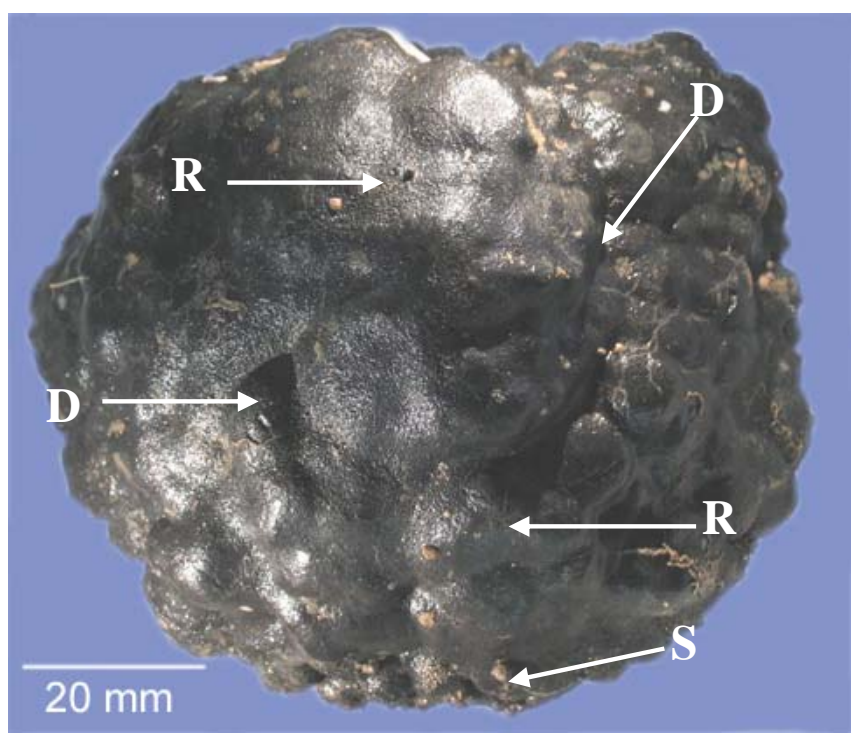

